\section{Jouko Vesikansa 1915-1987}

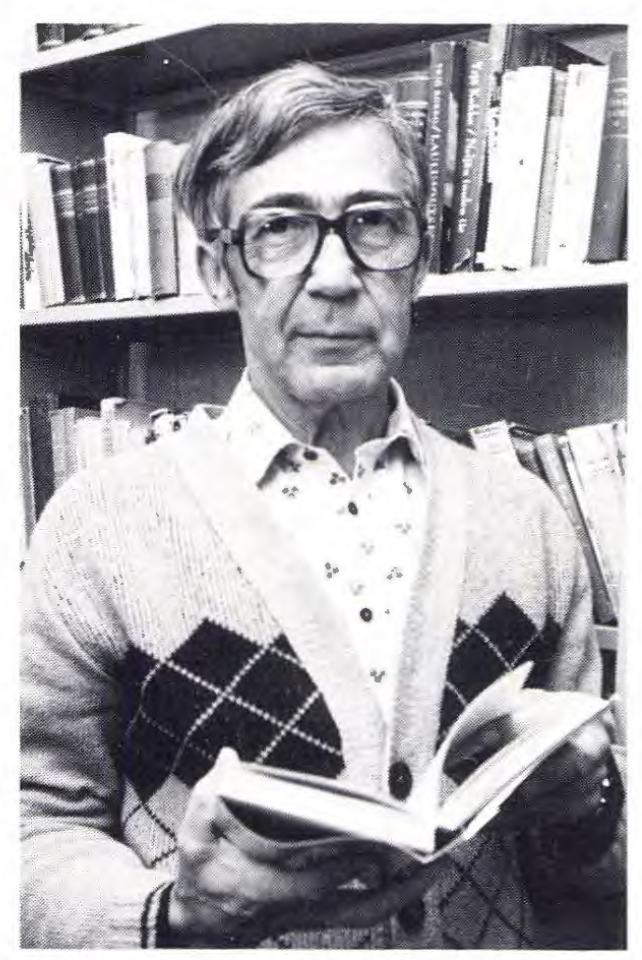

Kesäkuun 28. päivänä 1987 tuli matkansa päähän filosofian maisteri Jouko Vesikansa. Hänen kuolemansa ei ollut lähipiirille täysi yllätys, koska hänen tiedettiin jo pitkään poteneen vakavaa sairautta. Jouko Vesikansan lähtöön liittyi toisenlaista tragiikkaa: kielelle ja sanoille puoli vuosisataa uhrannut mies joutui elämään viimeisen vuotensa ilman sanoja, puhe- ja kirjoituskykynsä menettäneenä.

Jouko Vesikansa (vuoteen 1935 Sjöstedt) oli syntynyt Turussa 27 . huhtikuuta 1915 ja tullut ylioppilaaksi Tampereen klassillisesta lyseosta vuonna 1933. Ripeästi sujuneiden opintojen jälkeen hän valmistui jo syyskuussa 1937 filosofian kandidaatiksi Helsingin yliopistosta pääaineenaan suomen kieli. Opiskelun tehokkuutta korostaa vielä se, että yksi lukukausi kului Tarton yliopistossa viron opintojen parissa. Kohta valmistuttuaan eli alkuvuodesta 1938 Vesikansa tuli Suomalaisen Kirjallisuuden Seuran palvelukseen Nykysuomen sanakirjan toimittajaksi. Pitkä uurastus sanakirjatyön parissa alkoi.
Jouko Vesikansan tullessa Nykysuomen sanakirjan palvelukseen eivät kirjan toimitusperiaatteet vielä olleet täysin selkiytyneet. Työn pohjaksi oli kerätty nelisen miljoonaa sanalippua ja julkaistu suppeita näytevihkoja artikkelien rakenteen kokeilemiseksi. Rakennuksella oli vankka kivijalka, mutta seinät eivät vielä olleet nousseet. Jouko Vesikansa liittyi työhön vaiheessa, jossa hänen panoksensa tuli olennaisen tärkeäksi sanakirjan toimitusperiaatteiden luomisen kannalta. Sotavuosien aiheuttamien keskeytysten jälkeen toimitustyötä tehtiin ripeästi ja määrätietoisesti. Päätoimittajaksi oli nimitetty jo ennen sotia Matti Sadeniemi, ja vuoden 1946 alussa Jouko Vesikansasta tuli toimitussihteeri. Vesikansan harteille jäi artikkelien viimeistely painatusasuun. Tämän erittäin vaativan ja raskaan työvaiheen hän onnistui uurastamaan tuloksekkaasti yhdessä maisterien Arvo Keinosen ja Taito Piiroisen kanssa, niin että Nykysuomen sanakirjan ensimmäinen osa ilmestyi suunnitelmien mukaisesti vuonna 1951. Sen jälkeenkin tahti jatkui yhtä ripeänä, ja kymmenen vuotta myöhemmin oli nykysuomen sanavarojen monumentaalinen kuvaus kaikkien käytettävissä. Tämän vaiheen merkitystä Jouko Vesikansan elämässä on Esko Koivusalo luonnehtinut muistopuheessaan seuraavasti:

Sanakirjatyössä mukana olleet tietävät, ettei sanojen parissa uurastus ole aina kovin palkitsevaa. Työ on poikkeuksellisen pitkäjänteistä, tulokset tulevat julkisuuteen hitaasti, ja kiitosta saa yleensä vain kerran ihmisiässä. Jouko Vesikansan kohdalle loppuun suorittamisen suuri hetki sattui silloin, kun Nykysuomen sanakirja neljännesvuosisata sitten valmistui. Silloin tuli kiitosta vuosikymmenien uurastuksesta. Mutta tämä kiitos ei vienyt mukana olleita mitenkään näkyvästi uralla eteenpäin, eikä tunnustus muutoinkaan saanut mitään konkreettisia muotoja. Päinvastoin: Nykysuomen sanakirjan toimitus päästettiin hajoamaan. Vain pieni ydin, Jouko sen 
mukana, jäi jatkamaan sanakirjatöitä Suomen Akatemian kielitoimiston assistentteina.

Jouko Vesikansa sai siis tilaisuuden jatkaa leksikografin uraansa kielitoimistossa, joka myöhemmin siirtyi osaksi Kotimaisten kielten tutkimuskeskusta. Sanakirjatyö oli vienyt miehen kokonaan, ja tälle kutsumukselle Vesikansa pysyi uskollisena koko elämänsä ajan. Työpaikkakin säilyi koko ajan samana, vaikka organisaatio vaihtui moneen kertaan. 1960-luvulla Jouko Vesikansa oli mukana toimittamassa Nykysuomen sivistyssanakirjaa, joka ilmestyi 1973, ja 1970-luvun alkuvuosina hän käynnisti Nykysuomen perussanakirjan toimitustyön. Tämän sanakirjan päätoimittajana hän sitten oli eläkkeelle siirtymiseensä asti eli vuoden 1978 loppuun ja tuntityöntekijänä vielä senkin jälkeen useita vuosia.

Jouko Vesikansa kuului siihen sukupolveen, joka loi maahamme yksikielisen leksikografian perinteen. Se että nykyään voimme todella puhua perinteestä, on suurelta osalta Jouko Vesikansan ansiota. Hän näki selvästi jatkuvuuden merkityksen ja koulutti järjestelmällisesti nuorempia työtovereitaan. Hän oli kehittänyt kyvyn seuloa näennäisen kaoottisesta aineistosta olennaiset seikat ja kiteyttää ne tasapainoisiksi sanakirja-artikkeleiksi. Tuota taitoa hän pyrki persoonallisella tavallaan jakamaan nuorempien omaisuudeksi. Eikä hänen tukensa rajoittunut pelkästään tietopuoliseen ohjaukseen, vaan hän osasi myös kannustaa työtovereitaan vaikeina hetkinä. Sanoman ydin oli aina sama: "älä anna periksi, kyllä sinä osaat ja jaksat».

Sanakirjatyön ohella Jouko Vesikansa osallistui vuosikymmenten kuluessa monella tavoin käytännön kielenhuoltoon. Hän oli mukana kehittämässä esimerkiksi paperiteollisuuden ja hammaslääketieteen sanastoa, ja myös hänen toimintansa kielentarkastajana - mm. Valituissa Paloissa - oli mittavaa. Esimerkkeinä Vesikansan luomista uusista sanoista mainittakoon paperiteollisuuden termit erä- ja vuokeitto, perkipuristus, liukosellu, hierre ja pehmopaperi. Jo paljon ennemmin - vuoden 1940 seuduissa - hän oli eränkäyntisanastoa elvyttäen luonut pienen partiopojan nasevan nimityksen kolkkapoika, jonka sittemmin on tosin syrjäyttänyt kansainväliseen malliin pohjautuva "sudenpentu". Vain muutamien uudissanojen mainitseminen ei kuitenkaan anna oikeaa kuvaa tästä Vesikansan työn puolesta, koska suurin osa hänen sanaluomuksistaan on jäljittämättömissä. Kielitoimiston puhelinneuvonnalla on aina ollut kiinteä yhteys sanakirjatoimitukseen, ja vuosikymmenten aikana on Vesikansan sanaehdotuksia lähtenyt neuvonnan kautta matkaan varmasti sadoittain.

Nykysuomen sanakirjan toimitustyön aikana Jouko Vesikansalle tuli läheiseksi kielitiedon yleistajuistaminen. Oikeastaan tämä juonne läpäisee koko hänen elämäntyönsä. Myöhempinä vuosinaan hän ryhtyi laatimaan kokonaista kielitiedon ja kielenkäytön käsikirjasarjaa. Ensin ilmestyi joukko pakinoita suomen kielestä ja sen sanastosta nimellä Suomen kielen sanakirjo (julkaisija Markkinointi Viherjuuri 1975; täydennetyn laitoksen nimellä Miljoona sanaa kustansi WSOY 1978). Tämän jälkeen seurasi teossarja Nykysuomen oppaita, kustantajana WSOY. Ensimmäisenä oli vuorossa Täsmennyssanasto (1976), jossa valaistaan äänneasultaan toisilleen läheisten yleiskielen sanojen merkitys- ja käyttöeroja. Tämän jälkeen seurasivat tiheässä tahdissa oppaat Johdokset (1977), Lyhenteet (1979) ja Ulkomaiden paikannimet (1980).

Opaskirjoissaan ja yleensäkin kielenhuoltotyössään Jouko Vesikansa pysyi uskollisena periaatteilleen eikä pelännyt vastavirtaan soutamista. Tällöin hän ajautui esimerkiksi eräiden lyhennetyyppien pisteettömyyttä koskevissa kysymyksissä eri linjoille kuin E. N. Setälän ja Knut Cannelinin vakiinnuttama käytäntö, jota myös myöhemmässä kielen- 
huollossa on noudatettu Suomen Akatemian kielilautakunnan ja Kotimaisten kielten tutkimuskeskuksen suomen kielen lautakunnan tekemin vähäisin tarkistuksin. Tällaiset pienet poikkeamat eivät kuitenkaan olennaisesti vähennä Vesikansan oppaiden arvoa kielenkäyttäjien ja -tutkijoiden apuneuvoina.

Opiskellessaan Tarton yliopistossa syksyllä 1936 Jouko Vesikansa kiintyi syvästi Viroon ja virolaisuuteen, eikä tämä side päässyt koskaan katkeamaan. Aina viime vuosiin asti hän vieraili säännöllisesti Tallinnassa, ja hänen ystäväpiirinsä veljesmaassa oli laaja. Läheiset suhteet Viroon heijastuivat myös käytännön työhön. Vesikansa oli mukana toimittamassa Eestiläis-suomalaista sanakirjaa, joka ilmestyi Tallinnassa 1972, ja Eduard Väärin Viron kielen oppikirjaa (Suom. Kirj. Seura, Helsinki 1975).

Jouko Vesikansa oli väsymätön puurtaja. Hänellä oli aina vireillä monta hanketta yhtä aikaa, eikä hän pelännyt suuria haasteita. Kaikkea suunnittelemaansa hän ei ennättänyt viedä loppuun; Perussanakirjan viimeistely jäi muiden huoleksi ja Nykysuomen oppaita -sarja vajaaksi, eikä Vesikansa ehtinyt nähdä suunnittelemansa ja miltei valmiiksi toimittamansa leksikologisen kokoomateoksen ilmestymistä. Tämä nykysuomen sanastoa monesta näkökulmasta käsittelevä laaja teos tulee kuitenkin kirjakauppoihin ensi vuonna.

Jos Jouko Vesikansalle yrittäisi keksiä lyhyttä epiteettiä, ehkä yksi sopiva luonnehdinta olisi uuttera kielen palvelija. Kun hän joutui siirtymään hiljaisuuden maailmaan jo ennen kuolemaansa, tämänsuuntainen ajatus lienee tullut uudesta, järkyttävästä näkökulmasta monen mieleen. Uskon, että ne jotka ennen Jouko Vesikansan kuolemaa kuuntelivat yhdessä hänen kanssaan hetken aikaa hiljaisuutta, oppivat jotakin unohtumatonta sanojen merkityksestä. 